\title{
Connexin Mutants Compromise the Lens Circulation and Cause Cataracts through Biomineralization
}

\author{
Viviana M. Berthoud ${ }^{1, *}$, Junyuan Gao ${ }^{2}$, Peter J. Minogue ${ }^{1}$, Oscar Jara ${ }^{1}$, Richard T. Mathias ${ }^{2}$ and \\ Eric C. Beyer ${ }^{1}$ (D) \\ 1 Department of Pediatrics, University of Chicago, Chicago, IL 60637, USA; \\ pminogue@peds.bsd.uchicago.edu (P.J.M.); ojaraleiva@peds.bsd.uchicago.edu (O.J.); \\ ecbeyer@uchicago.edu (E.C.B.) \\ 2 Department of Physiology and Biophysics, Stony Brook University, Stony Brook, NY 11794, USA; \\ junyuan.gao@stonybrook.edu (J.G.); richard.mathias@stonybrook.edu (R.T.M.) \\ * Correspondence: vberthou@peds.bsd.uchicago.edu; Tel.: +1-773-834-2115
}

Received: 7 July 2020; Accepted: 6 August 2020; Published: 13 August 2020

\begin{abstract}
Gap junction-mediated intercellular communication facilitates the circulation of ions, small molecules, and metabolites in the avascular eye lens. Mutants of the lens fiber cell gap junction proteins, connexin46 (Cx46) and connexin50 (Cx50), cause cataracts in people and in mice. Studies in mouse models have begun to elucidate the mechanisms by which these mutants lead to cataracts. The expression of the dominant mutants causes severe decreases in connexin levels, reducing the gap junctional communication between lens fiber cells and compromising the lens circulation. The impairment of the lens circulation results in several changes, including the accumulation of $\mathrm{Ca}^{2+}$ in central lens regions, leading to the formation of precipitates that stain with Alizarin red. The cataract morphology and the distribution of Alizarin red-stained material are similar, suggesting that the cataracts result from biomineralization within the organ. In this review, we suggest that this may be a general process for the formation of cataracts of different etiologies.
\end{abstract}

Keywords: cataract; intercellular communication; connexin mutant; calcium; calcification; biomineralization

\section{Introduction}

Intercellular communication mediated by gap junctions is critical to the function of many organs. Gap junctions are plasma membrane specializations containing intercellular channels that allow the passage of cytoplasmic ions and small molecules (up to $\sim 1 \mathrm{kDa}$ ) directly from cell to cell. They are formed by the coaxial alignment of two hemichannels; one is contributed by each of the closely apposed cells. The gap junction hemichannel is a hexameric assembly of protein subunits called connexins. Mutations of the genes encoding the connexins have been linked to a wide spectrum of diseases. The genetic disruption of the connexin-encoding genes can cause additional pathologies. Studies of the connexins expressed in the eye lens have provided unique insights into the mechanisms by which connexin mutants and loss of intercellular communication lead to disease. In this article, we summarize the findings of these studies and emphasize our recent observations.

\section{The Lens and Its Specialized Cells}

The lens is an avascular organ formed by an anterior surface epithelium, with the bulk of the tissue formed by fiber cells. In the equatorial region, epithelial cells give rise to differentiating fiber cells, which become mature fiber cells through a process that involves cell elongation and loss of organelles, including the nuclei (Figure 1). The main function of the lens is to transmit and focus light onto the retina. This function is facilitated by several specializations. The loss of organelles minimizes 
light scattering. The fiber cells are narrow and organized with little extracellular space between them, minimizing light scattering at the cell borders. They contain a very high concentration of water-soluble proteins, referred to as crystallins, which have a liquid-like or glass-like, short-range spatial order that limits density fluctuations and light scattering [1,2].
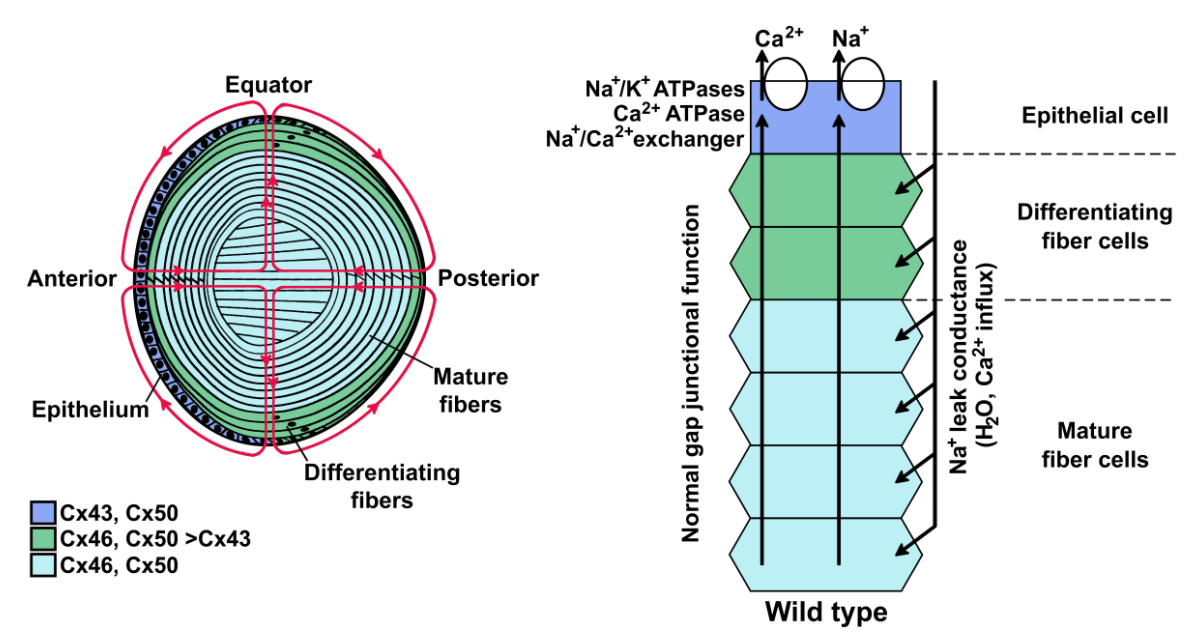

Figure 1. The lens and its internal circulation. Left, the diagram illustrates the distribution of connexins in the different regions of the lens and the circulation of ions and fluid (magenta lines with arrowheads to indicate direction of flow). Cells from the anterior epithelium express connexin43 (Cx43) and connexin50 (Cx50). Differentiating fiber cells express Cx43, connexin46 (Cx46), and Cx50, but the expression of $\mathrm{Cx} 43$ is downregulated as differentiation proceeds. Mature fiber cells express $\mathrm{Cx} 46$ and Cx50. In the lens circulation, ions and fluid enter into the extracellular spaces at the anterior and posterior poles and they exit across epithelial cell membranes at the equator. Right, the diagram depicts the ion circulation and some of the components that support it in a cellular column encompassing the lens surface to its center. Ions enter differentiating fiber and mature fiber cells through the plasma membrane driven by their electrochemical gradient, and they move back to the surface from cell-to-cell through gap junction-mediated electro-diffusion and advection. Once they reach the cells in the epithelium, the ions are transported out of the lens by pumps and transporters. Modified from Gao et al. (left panel, Figure 1; right panel, Figure 8A) [3].

\section{Intercellular Communication and Healthy Survival of the Lens}

Although fiber cells lose their organelles as they mature, various mechanisms ensure their survival. Fiber cells are connected to each other through specialized intercellular junctions, including gap junctions. In people, mature lens fiber cells express two connexins: connexin46 (Cx46) and connexin50 (Cx50).

The maintenance of cellular homeostasis in the lens is supported by an internal circulation system. This circulation is driven by the regional distribution and activities of ion channels, transporters, and exchangers (reviewed by Mathias et al. [4]). It allows ions and nutrients to reach the center of the lens and unwanted metabolites to move from the center to superficial cells, where they can be expelled. In the circulation model (Figure 1), ions (e.g., $\mathrm{Na}^{+}$and $\mathrm{Ca}^{2+}$ ) enter the lens at the anterior and posterior poles and move to the center through the extracellular spaces. As the ions proceed towards the lens center, they are driven into fiber cells by their transmembrane electrochemical gradients. The outward movement of cytoplasmic ions from fiber cells in the lens center to the epithelial cells on the lens surface occurs by cell-to-cell diffusion, conduction, and advection through gap junction channels. The circuit of the lens circulation is completed when ions are transported out of the lens by epithelial $\mathrm{Na}^{+} / \mathrm{K}^{+}$-ATPases (for $\mathrm{Na}^{+}$) or by the epithelial $\mathrm{Na}^{+} / \mathrm{Ca}^{2+}$ exchanger and $\mathrm{Ca}^{2+}$-ATPase (for $\mathrm{Ca}^{2+}$ ). The ions do not move alone; their transmembrane fluxes create transmembrane osmotic gradients, coupling the movement of fluid to the circulation of ions (Figure 1). Under normal conditions, the lens may compensate for a brief disturbance of the lens circulation by increasing/decreasing the activities of ion channels, solute carriers, transporters, and/or exchangers. 


\section{Lens Disease and Connexins}

The most common disease of the lens is the development of cataracts. A cataract is a cloudiness or opacity in the lens that disrupts normal light transmission and its focusing onto the retina. Cataracts are the leading cause of blindness worldwide [5]. They are often associated with aging and can be caused by a variety of diseases and environmental factors. Congenital cataracts are the most common cause of childhood visual impairment, accounting for $10 \%$ of childhood blindness [6]. About half of congenital cataract cases have a genetic basis, with many linked to mutations in the genes encoding major lens proteins (including those of Cx46 and Cx50).

Cataract-associated mutations have been identified at more than 40 different positions in the genes encoding Cx46 (Gja3) and Cx50 (Gja8) in human pedigrees [7]. Most of the connexin mutants lead to cataracts with an autosomal dominant inheritance pattern, and most of the mutants that have been investigated are non-functional when studied using expression systems (reviewed in Berthoud and Ngezahayo [8]). Since gap junctions are an important component of the lens circulation, the results of the in vitro studies suggest that most cataract-linked lens connexin mutants will reduce lens gap junctional coupling and affect the lens circulation. In addition, connexin mutants with increased hemichannel activity (but normal gap junction channel activity) could potentially affect the lens circulation by depolarizing the cells, which would decrease the driving force for the movement of ions throughout the organ.

Because it is not possible to study the consequences of Cx46 or Cx50 mutants expressed in human lenses, these mutants have been assessed in mouse models. Mice with homozygous (but not heterozygous) targeted deletion of Cx46 or Cx50 develop cataracts [9-11]. Mice with mutations in the $\mathrm{C} \times 46$ or $\mathrm{C} \times 50$ genes develop cataracts that are inherited with a dominant or semi-dominant pattern [12-17]. The lenses of mice with targeted deletion of $\mathrm{Cx} 46$ or Cx50, or with dominant mutations in either of these genes, have very reduced levels of $C \times 46$ and/or Cx50 [10,11,16-18] and of intercellular communication between lens fiber cells (measured as an increase in intracellular resistivity) [18-21]. Transgenic mice with lens over-expression of a mutant ubiquitin (K6W-Ub) that is conjugation competent but proteolytically incompetent also have decreased gap junctional coupling between fiber cells in the core of the lens, likely because these mice have lower levels of $C \times 46$, as detected by immunoblotting [22]. These results suggest that any gene mutation/deletion or insult that leads to a drastic decrease in the abundance and/or function of connexins in lens fiber gap junctions may reduce coupling between fiber cells.

Other parameters related to the lens circulation have been determined in these lenses. The hydrostatic pressure is increased in lenses from heterozygous $\mathrm{Cx} 46$ knockout mice and lenses from mice expressing Cx46 or Cx50 dominant mutants [3,21,23]. The intracellular concentration of $\mathrm{Na}^{+}$is increased in lenses from Cx46 mutant mice [3]. The intracellular concentration of $\mathrm{Ca}^{2+}\left(\left[\mathrm{Ca}^{2+}\right]_{i}\right)$ is increased in the lens fiber cells from homozygous Cx46 knockout mice, transgenic $\mathrm{K} 6 \mathrm{~W}-\mathrm{Ub}$ mice, and mice expressing Cx46 or Cx50 mutants $[3,21,22,24]$. The emerging picture from these results is that decreased intercellular communication between lens fiber cells leads to an increased gradient of hydrostatic pressure and elevated gradients of the intracellular concentrations of sodium ions and calcium ions [3,21-24]. It is likely that gap junctional coupling is also impaired in cataractous lenses from mice homozygous for the $\gamma \mathrm{B}$-crystallin S11R mutation, because these lenses have severely decreased levels of Cx46 and Cx50 and increased total $\mathrm{Ca}^{2+}$. This inference is supported by the observation that the knock-in of $\mathrm{Cx} 46$ into the Cx50 locus suppressed the nuclear cataract [25]. Extrapolation to humans suggests that people carrying a mutation or suffering a lens insult that severely decreases connexin levels or gap junction function likely develop cataracts due to impairment of the lens circulation.

\section{Calcium Ions in the Normal and Cataractous Lens}

As in other cell types, $\mathrm{Ca}^{2+}$ homeostasis in the lens fiber cells depends on the binding/sequestration of intracellular $\mathrm{Ca}^{2+}$ and on the balance between ion influx and efflux. The $\left[\mathrm{Ca}^{2+}\right]_{i}$ in the lens can be modulated through storage of the ion in organelles, including the endoplasmic reticulum and 
mitochondria, and through its binding by cytoplasmic proteins. The organellar sequestration of $\mathrm{Ca}^{2+}$ can only occur in surface cells, because the organelles are absent in the mature fiber cells. Calcium-binding cytoplasmic proteins (including calmodulin and some crystallins) contribute to the buffering of $\mathrm{Ca}^{2+}$ in all cells, and they provide the only mechanism in mature fiber cells.

Lens $\mathrm{Ca}^{2+}$ influx depends on entry through plasma membrane channels in interior fiber and surface cells. Voltage-dependent $\mathrm{Ca}^{2+}$-selective channels have been identified in lens epithelial and surface fiber cells, as have other channels that would allow $\mathrm{Ca}^{2+}$ permeation, such as TRP channels [26-29]. The movement of extracellular $\mathrm{Ca}^{2+}$ from the surface of the lens to its center is driven by diffusion, conduction, and advection. As extracellular calcium ions move inward, they are driven by the $\mathrm{Ca}^{2+}$ transmembrane electrochemical gradient to enter the more central cells through the fiber cell membrane's $\mathrm{Ca}^{2+}$ permeability. Lens intracellular calcium ions move through gap junctions to surface cells where efflux is driven by active transport by the $\mathrm{Ca}^{2+}$-ATPase and $\mathrm{Na}^{+} / \mathrm{Ca}^{2+}$ exchanger; it may be influenced by a recently identified $\mathrm{K}^{+}$-dependent $\mathrm{Na}^{+} / \mathrm{Ca}^{2+}$ exchanger (Nckx4) in outer cortical fibers [30].

How is the $\mathrm{Ca}^{2+}$ efflux from surface cells connected to the $\mathrm{Ca}^{2+}$ influx in mature fiber cells located in more central regions of the lens? These spatially distant processes can be coordinated because the extensive network of lens fiber gap junction channels provides coupling throughout the organ. Gap junction-mediated intercellular communication allows the electro-diffusion and advection of $\mathrm{Ca}^{2+}$ from the center of the lens towards the site of active ion transport in surface cells.

In the normal (wild type) mouse lens, the $\left[\mathrm{Ca}^{2+}\right]_{\mathrm{i}}$ gradually increases from the lens surface to the center, forming a gradient that can be described by a parabolic function [24]. However, in the lenses of connexin mutant mice, Cx46-null mice, or mice with substantially decreased Cx46 levels, the $\left[\mathrm{Ca}^{2+}\right]_{\mathrm{i}}$ increases beyond the levels in wild type lenses at all radial distances from the lens center $[3,21,22,24]$. The extent to which the radial $\left[\mathrm{Ca}^{2+}\right]_{\mathrm{i}}$ can be fit to a parabola differs in the mutant mouse lenses. In the Cx46 and Cx50 mutant mice, it fits only up to a partial depth into the lens (from the lens surface); the $\left[\mathrm{Ca}^{2+}\right]_{i}$ in the central region does not fit to this equation (Figure 2) [3,21]. Thus, in the centers of the connexin mutant lenses, the influx of $\mathrm{Ca}^{2+}$ surpasses efflux and buffering, and calcium ions accumulate. Mutant lens connexins with increased hemichannel activity may also lead to significant increases in the $\left[\mathrm{Ca}^{2+}\right]_{i}$, as these hemichannels provide a conduit for the equilibration of the intracellular and extracellular concentrations of all permeant ions and molecules, including $\mathrm{Ca}^{2+}$.
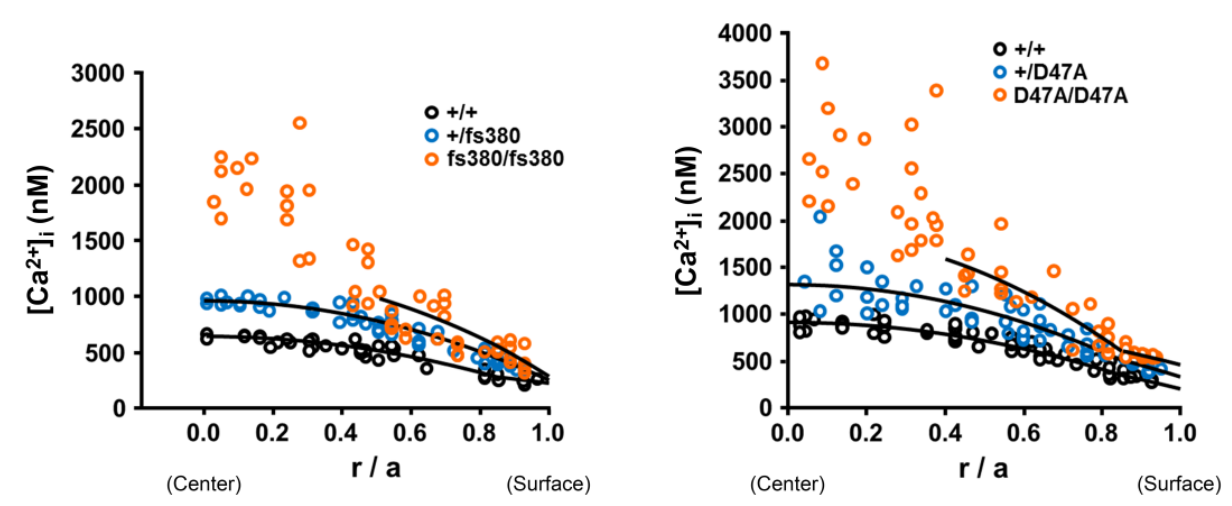

Figure 2. Intracellular calcium ion concentrations are increased in Cx46fs380 and Cx50D47A lenses. Graphs show the intracellular calcium concentrations $\left(\left[\mathrm{Ca}^{2+}\right]_{\mathrm{i}}\right.$ ) in wild type (black circles), heterozygous (blue circles) and homozygous (orange circles) Cx46fs380 (left) and Cx50D47A (right) lenses as a function of radial distance from the lens center $(\mathrm{r} ; \mathrm{cm})$, normalized to the lens radius $(\mathrm{a} ; \mathrm{cm})$. The curves represent the best fit to the data based on the model described in Gao et al. [24]. Reproduced from Gao et al. (Figure 6J) [3] and Berthoud et al. (Figure 6D) [21].

\section{The Cataractous Lens: A Mineralized Organ?}

The biochemical changes present in lenses with cataracts due to different causes have been extensively studied. Abnormalities include the formation of high molecular weight protein aggregates, 
post-translational modification of lens proteins, protein cleavage, and protein degradation (reviewed in [31-33]). Calcium has also been implicated in cataract pathogenesis [34]. Human and mouse lenses with cataracts of different etiologies contain increased $\mathrm{Ca}^{2+}[22,24,25,35-37]$. As noted above, we found an increased $\left[\mathrm{Ca}^{2+}\right]_{\mathrm{i}}$ in the lenses of mice carrying a Cx46 or Cx50 mutant $[3,21]$.

Because calcium salts have relatively low solubilities in aqueous solutions and the $\left[\mathrm{Ca}^{2+}\right]_{i}$ detected in cataractous lenses $[3,21,22,24]$ reaches values of $>1000 \mathrm{nM}$ in the center of the lens, it seemed likely that $\mathrm{Ca}^{2+}$ would precipitate. This hypothesis is supported by reports of increased calcium associated with the insoluble lens fraction (as compared with the soluble fraction) of cataractous human lenses [35] and the finding of calcium oxalate or calcium carbonate crystals in human cataractous lenses [38-40].

We identified immobile $\mathrm{Ca}^{2+}$ in cataractous lenses from mice expressing $\mathrm{Cx} 46$ or $\mathrm{Cx} 50$ mutants by whole-mount staining with Alizarin red, a dye used to detect insoluble $\mathrm{Ca}^{2+}$ in other tissues (Figure 3). Interestingly, performing the staining in whole-mounts allowed us to observe that the pattern of Alizarin red staining resembles the morphology of the cataract $[3,21]$. This observation suggests that these cataracts are largely generated by the formation of insoluble calcium salts (minerals).


Figure 3. Alizarin red stains $\mathrm{Ca}^{2+}$-containing precipitates in Cx46fs380 and Cx50D47A cataracts. Lenses from wild type (+/+) and homozygous Cx46fs380 (fs380/fs380) or Cx50D47A (D47A/D47A) mice were photographed using darkfield illumination (top panels) and after whole-mount staining with Alizarin red (bottom panels). Arrowheads in the homozygous Cx50D47A lens point to the Alizarin red-stained precipitates that can be mapped to the cataract outline. The agreement between the Alizarin red staining and the cataract shape suggests that the spatial distribution of the $\mathrm{Ca}^{2+}$-containing precipitates determines the cataract morphology. Scale bars: 750 and $780 \mu \mathrm{m}$ for darkfield and Alizarin red-stained images of Cx46fs380 lenses, respectively; $591 \mu \mathrm{m}$ for Cx50D47A lenses. Modified from Gao et al. (Figure 7, Cx46fs380 panels) [3] and Berthoud et al. (Figure 7, Cx50D47A panels) [21].

\section{Cataracts May Result from Biomineralization in the Lens}

Biomineralization is the formation of mixed deposits comprised of organic materials and insoluble precipitates/crystals containing inorganic ions [41]. It occurs normally in some tissues (such as bone and teeth), but it is a pathologic process in others (such as the generation of kidney stones and calcification of blood vessels) [42]. The initial step in biomineralization is the formation of a nucleation particle. Subsequently, other material deposits upon this particle. In lenses with an impaired lens circulation that causes $\mathrm{Ca}^{2+}$ accumulation (as in mice with $\mathrm{Cx} 46$ or $\mathrm{Cx} 50$ gene mutations), we postulate that the first step is the precipitation of calcium salts after the intracellular concentrations of $\mathrm{Ca}^{2+}$ and the corresponding anions surpass their $K_{\text {sp }}$ (Figure 4 ). 


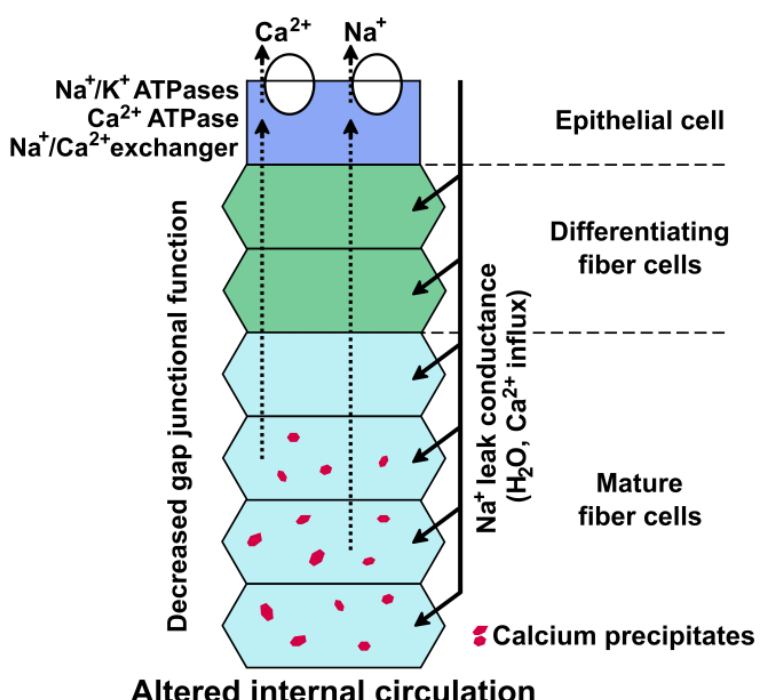

Figure 4. Lens connexin mutants alter the lens circulation. The diagram shows the lens circulation in a cellular column of a homozygous connexin mutant lens to illustrate the effects of the expression of the connexin mutant. The expression of a mutant connexin decreases the gap junction-mediated circulation of ions (dotted lines). An increase in $\left[\mathrm{Na}^{+}\right]_{\mathrm{i}}$ leads to a decrease in the activity of the $\mathrm{Na}^{+} / \mathrm{Ca}^{2+}$ exchanger. An increase in $\left[\mathrm{Ca}^{2+}\right]_{\mathrm{i}}$ above $1 \mu \mathrm{M}$ exceeds the buffering capacity, resulting in the formation of $\mathrm{Ca}^{2+}$-containing precipitates. Modified from Gao et al. (Figure 8B) [3].

Although biomineralization of bone and teeth occurs in the extracellular matrix, it is likely that the initial formation of precipitated calcium salts occurs inside the lens fiber cells of the connexin mutant lenses, where the intracellular concentrations of calcium ions and their counterions have surpassed their $K_{\mathrm{sp}}$. These precipitates act as nucleation particles for the deposit of other molecules, including proteins, lipids, and/or additional $\mathrm{Ca}^{2+}$ (or other cation) salts (Figure 5). As the calcium precipitates grow, they can remain inside the cell or they may eventually disrupt the integrity of the plasma membrane and become extracellular. These biomineral deposits are detected as cataracts.

\section{Steps in biomineralization Mechanism of cataract formation}

Formation of a nucleation particle

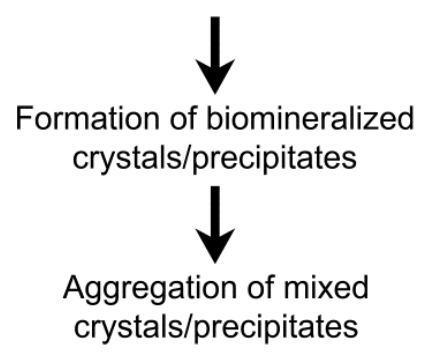

Supersaturation of lens cell cytoplasm with $\mathrm{Ca}^{2+}$ and crystallization

Deposit of additional $\mathrm{Ca}^{2+}$ and lens proteins on the nucleation particle

Formation of conglomerates of $\mathrm{Ca}^{2+}$ salt crystals and lens proteins

Figure 5. The proposed mechanism by which calcium ions contribute to cataract formation through biomineralization. Lenses from mice with disruptions of the lens circulation due to mutations of Cx46 or $\mathrm{Cx} 50$ accumulate $\mathrm{Ca}^{2+}$. When the $K_{\mathrm{sp}}$ for calcium salts is surpassed, the salts precipitate and act as a nucleation particle. Then, more calcium salts and lens proteins deposit over the nucleation particle. With time, this leads to the formation of an aggregate containing a mix of calcium salts and lens proteins, i.e., a deposit of biomineral.

Alterations of the lens circulation and subsequent biomineralization in the lens may be affected by modifications of the connexins. The lens fiber connexins can undergo several post-translational modifications, including acetylation, phosphorylation, ubiquitination, carbonylation, nitrosation, 
and cleavage [43-49]. Their effect on gap junction or hemichannel function is known in some cases. The modeling of gap junction intercellular channels made of Cx46 and/or Cx50 suggests that $\mathrm{N}$-terminal acetylation of these connexins increases their cation-to-anion specificity [47]. The effects of phosphorylation depend on the protein kinase, the substrate amino acid residue, and the connexin subtype. It can alter gap junction intercellular communication and channel and hemichannel permeability [50-55], and can also affect connexin stability [56,57]. Cleavage has been implicated in changing the $\mathrm{pH}$ sensitivity of the lens fiber connexin channels, but this effect varies between connexin subtypes and animal species [58-62]. Cleavage can be regulated by phosphorylation [63]. The S-nitrosation of Cx46 (induced with NO donors) increases its hemichannel tail currents and inactivation at positive voltages of $50-60 \mathrm{mV}$, but does not affect the electrophysiological properties of the Cx46 gap junction channels [48]. The carbonylation of Cx46 (induced with 4-hydroxynonenal) decreases its hemichannel currents and dye uptake [49].

Our model for cataract formation may also have implications regarding the pathogenesis of age-related cataracts. Since lens fiber cell connexins have a much longer half-life than other members of the connexin family and mature lens fiber cells lose the synthetic machinery necesssary to replace old/damaged connexins by newly synthesized ones, the connexins can accumulate modifications with aging. These modifications may cause the deterioration of gap junctional intercellular communication and/or an increase in connexin hemichannel activity (and thereby an impairment of the lens circulation), leading to an increase in the $\left[\mathrm{Ca}^{2+}\right]_{i}$ to a sufficiently high level that calcium ions start precipitating. However, the healthy aging lens must also have protective/compensatory mechanisms, since the lenses of 14-month old mice can remain free of cataracts, despite reduced lens intercellular communication and $\mathrm{Ca}^{2+}$ accumulation [64].

\section{Potential Generality of the Biomineralization Model for Cataract Formation}

Our results suggest that any process that impairs the lens circulation (such as mutations in the lens fiber cell connexin genes) can cause cataracts through $\mathrm{Ca}^{2+}$ accumulation, precipitation, and biomineralization. The insoluble material in these cataractous lenses likely contains aggregated or denatured proteins, in addition to the precipitated $\mathrm{Ca}^{2+}$ salts. Lens biomineralization might be the key to the formation of cataracts of other etiologies. In other systems/tissues, various proteins participate in initiating the process of mineralization [65]. Thus, in cataracts that do not start through disruption of the lens circulation, the initial step might be the denaturation and/or aggregation of lens proteins that subsequently act as a surface for the deposit of $\mathrm{Ca}^{2+}$ salts, followed by the growth of mixed aggregates detectable as significant opacities.

Author Contributions: Writing-original draft preparation, V.M.B.; writing—review and editing, V.M.B., J.G., P.J.M., O.J., R.T.M., E.C.B. All authors have read and agreed to the published version of the manuscript.

Funding: This work was supported by the National Institutes of Health National Eye Institute Grant R01 EY-08368 (to E.C.B.).

Conflicts of Interest: The authors declare no conflict of interest.

\section{Abbreviations}

$\begin{array}{ll}{\left[\mathrm{Ca}^{2+}\right]_{\mathrm{i}}} & \text { Intracellular concentration of calcium ions } \\ \mathrm{C} \times 43 & \text { Connexin } 43 \\ \mathrm{C} \times 46 & \text { Connexin } 46 \\ \mathrm{C} \times 50 & \text { Connexin50 } \\ \mathrm{K} 6 \mathrm{~W}-\mathrm{Ub} & \text { Ubiquitin K6W mutant } \\ K_{\mathrm{sp}} & \text { Solubility product constant } \\ \mathrm{NO} & \text { Nitric oxide }\end{array}$




\section{References}

1. Delaye, M.; Tardieu, A. Short-range order of crystallin proteins accounts for eye lens transparency. Nature 1983, 302, 415-417. [CrossRef] [PubMed]

2. Ponce, A.; Sorensen, C.; Takemoto, L. Role of short-range protein interactions in lens opacifications. Mol. Vis. 2006, 12, 879-884. [PubMed]

3. Gao, J.; Minogue, P.J.; Beyer, E.C.; Mathias, R.T.; Berthoud, V.M. Disruption of the lens circulation causes calcium accumulation and precipitates in connexin mutant mice. Am. J. Physiol. Cell Physiol. 2018, 314, C492-C503. [CrossRef] [PubMed]

4. Mathias, R.T.; Kistler, J.; Donaldson, P. The lens circulation. J. Membr. Biol. 2007, 216, 1-16. [CrossRef]

5. Resnikoff, S.; Pascolini, D.; Etya'ale, D.; Kocur, I.; Pararajasegaram, R.; Pokharel, G.P.; Mariotti, S.P. Global data on visual impairment in the year 2002. Bull. World Health Organ. 2004, 82, 844-851.

6. Francis, P.J.; Moore, A.T. Genetics of childhood cataract. Curr. Opin. Ophthalmol. 2004, 15, 10-15. [CrossRef]

7. Shiels, A.; Bennett, T.M.; Hejtmancik, J.F. Cat-Map: Putting cataract on the map. Mol. Vis. 2010, 16, $2007-2015$.

8. Berthoud, V.M.; Ngezahayo, A. Focus on lens connexins. BMC Cell Biol. 2017, 18 (Suppl. 1), 6. [CrossRef]

9. Gong, X.; Li, E.; Klier, G.; Huang, Q.; Wu, Y.; Lei, H.; Kumar, N.M.; Horwitz, J.; Gilula, N.B. Disruption of $\alpha_{3}$ connexin gene leads to proteolysis and cataractogenesis in mice. Cell 1997, 91, 833-843. [CrossRef]

10. White, T.W.; Goodenough, D.A.; Paul, D.L. Targeted ablation of connexin50 in mice results in microphthalmia and zonular pulverulent cataracts. J. Cell Biol. 1998, 143, 815-825. [CrossRef]

11. Rong, P.; Wang, X.; Niesman, I.; Wu, Y.; Benedetti, L.E.; Dunia, I.; Levy, E.; Gong, X. Disruption of Gja8 ( $\alpha 8$ connexin) in mice leads to microphthalmia associated with retardation of lens growth and lens fiber maturation. Development 2002, 129, 167-174.

12. Steele, E.C., Jr.; Lyon, M.F.; Favor, J.; Guillot, P.V.; Boyd, Y.; Church, R.L. A mutation in the connexin 50 (Cx50) gene is a candidate for the No2 mouse cataract. Curr. Eye Res. 1998, 17, 883-889. [CrossRef]

13. Graw, J.; Löster, J.; Soewarto, D.; Fuchs, H.; Meyer, B.; Reis, A.; Wolf, E.; Balling, R.; Hrabé de Angelis, M. Characterization of a mutation in the lens-specific MP70 encoding gene of the mouse leading to a dominant cataract. Exp. Eye Res. 2001, 73, 867-876. [CrossRef] [PubMed]

14. Chang, B.; Wang, X.; Hawes, N.L.; Ojakian, R.; Davisson, M.T.; Lo, W.-K.; Gong, X. A Gja8 (Cx50) point mutation causes an alteration of $\alpha 3$ connexin (Cx46) in semi-dominant cataracts of Lop10 mice. Hum. Mol. Genet. 2002, 11,507-513. [CrossRef] [PubMed]

15. Xia, C.-h.; Chang, B.; DeRosa, A.M.; Cheng, C.; White, T.W.; Gong, X. Cataracts and microphthalmia caused by a Gja8 mutation in extracellular loop 2. PLoS ONE 2012, 7, e52894. [CrossRef] [PubMed]

16. Berthoud, V.M.; Minogue, P.J.; Yu, H.; Schroeder, R.; Snabb, J.I.; Beyer, E.C. Connexin50D47A decreases levels of fiber cell connexins and impairs lens fiber cell differentiation. Investig. Ophthalmol. Vis. Sci. 2013, 54, 7614-7622. [CrossRef]

17. Berthoud, V.M.; Minogue, P.J.; Yu, H.; Snabb, J.I.; Beyer, E.C. Connexin46fs380 causes progressive cataracts. Investig. Ophthalmol. Vis. Sci. 2014, 55, 6639-6648. [CrossRef]

18. Gong, X.; Baldo, G.J.; Kumar, N.M.; Gilula, N.B.; Mathias, R.T. Gap junctional coupling in lenses lacking $\alpha_{3}$ connexin. Proc. Natl. Acad. Sci. USA 1998, 95, 15303-15308. [CrossRef]

19. Baldo, G.J.; Gong, X.; Martinez-Wittinghan, F.J.; Kumar, N.M.; Gilula, N.B.; Mathias, R.T. Gap junctional coupling in lenses from $\alpha_{8}$ connexin knockout mice. J. Gen. Physiol. 2001, 118, 447-456. [CrossRef]

20. Minogue, P.J.; Gao, J.; Zoltoski, R.K.; Novak, L.A.; Mathias, R.T.; Beyer, E.C.; Berthoud, V.M. Physiological and optical alterations precede the appearance of cataracts in Cx46fs380 mice. Investig. Ophthalmol. Vis. Sci. 2017, 58, 4366-4374. [CrossRef]

21. Berthoud, V.M.; Gao, J.; Minogue, P.J.; Jara, O.; Mathias, R.T.; Beyer, E.C. The connexin50D47A mutant causes cataracts by calcium precipitation. Investig. Ophthalmol. Vis. Sci. 2019, 60, 2336-2346. [CrossRef] [PubMed]

22. Liu, K.; Lyu, L.; Chin, D.; Gao, J.; Sun, X.; Shang, F.; Caceres, A.; Chang, M.-L.; Rowan, S.; Peng, J.; et al. Altered ubiquitin causes perturbed calcium homeostasis, hyperactivation of calpain, dysregulated differentiation, and cataract. Proc. Natl. Acad. Sci. USA 2015, 112, 1071-1076. [CrossRef] [PubMed]

23. Gao, J.; Sun, X.; Moore, L.C.; White, T.W.; Brink, P.R.; Mathias, R.T. Lens intracellular hydrostatic pressure is generated by the circulation of sodium and modulated by gap junction coupling. J. Gen. Physiol. 2011, 137, 507-520. [CrossRef] 
24. Gao, J.; Sun, X.; Martinez-Wittinghan, F.J.; Gong, X.; White, T.W.; Mathias, R.T. Connections between connexins, calcium, and cataracts in the lens. J. Gen. Physiol. 2004, 124, 289-300. [CrossRef]

25. Li, L.; Cheng, C.; Xia, C.-h.; White, T.W.; Fletcher, D.A.; Gong, X. Connexin mediated cataract prevention in mice. PLoS ONE 2010, 5, e12624. [CrossRef]

26. Shahidullah, M.; Mandal, A.; Delamere, N.A. TRPV4 in porcine lens epithelium regulates hemichannelmediated ATP release and Na-K-ATPase activity. Am. J. Physiol. Cell Physiol. 2012, 302, C1751-C1761. [CrossRef]

27. Maddala, R.; Nagendran, T.; de Ridder, G.G.; Schey, K.L.; Rao, P.V. L-type calcium channels play a critical role in maintaining lens transparency by regulating phosphorylation of aquaporin- 0 and myosin light chain and expression of connexins. PLoS ONE 2013, 8, e64676. [CrossRef]

28. Martínez-García, M.C.; Martínez, T.; Pañeda, C.; Gallego, P.; Jimenez, A.I.; Merayo, J. Differential expression and localization of transient receptor potential vanilloid 1 in rabbit and human eyes. Histol. Histopathol. 2013, 28, 1507-1516.

29. Bennett, T.M.; Mackay, D.S.; Siegfried, C.J.; Shiels, A. Mutation of the melastatin-related cation channel, TRPM3, underlies inherited cataract and glaucoma. PLOS ONE 2014, 9, e104000. [CrossRef]

30. De Maria, A.; Zhao, H.; Bassnett, S. Expression of potassium-dependent sodium-calcium exchanger in the murine lens. Exp. Eye Res. 2018, 167, 18-24. [CrossRef]

31. Sharma, K.K.; Santhoshkumar, P. Lens aging: Effects of crystallins. Biochim. Biophys. Acta 2009, 1790, 1095-1108. [CrossRef] [PubMed]

32. Zhang, K.; Zhu, X.; Lu, Y. The proteome of cataract markers: Focus on crystallins. Adv. Clin. Chem. 2018, 86, 179-210. [PubMed]

33. Truscott, R.J.W.; Friedrich, M.G. Molecular processes implicated in human age-related nuclear cataract. Investig. Ophthalmol. Vis. Sci. 2019, 60, 5007-5021. [CrossRef] [PubMed]

34. Burge, W.E. Analysis of the ash of the normal and the cataractous lens. Arch. Ophthalmol. 1909, 38, 435-450.

35. Duncan, G.; van Heyningen, R. Distribution of non-diffusible calcium and sodium in normal and cataractous human lenses. Exp. Eye Res. 1977, 25, 183-193. [CrossRef]

36. Duncan, G.; Jacob, T.J. Calcium and the physiology of cataract. Ciba Found. Symp. 1984, 106, 132-152.

37. Hightower, K.R.; Reddy, V.N. Calcium content and distribution in human cataract. Exp. Eye Res. 1982, 34, 413-421. [CrossRef]

38. Zimmerman, L.E.; Johnson, F.B. Calcium oxalate crystals within ocular tissues. A clinicopathologic and histochemical study. AMA Arch. Ophthalmol. 1958, 60, 372-383. [CrossRef]

39. Bron, A.J.; Habgood, J.O. Morgagnian cataract. Trans. Ophthalmol. Soc. U.K. 1976, 96, 265-277.

40. Pau, H. Spheroliths in the lens. Klin. Monbl. Augenheilkd. 1984, 184, 159-162. [CrossRef]

41. Weiner, S.; Dove, P.M. An overview of biomineralization processes and the problem of the vital effect. Rev. Mineral. Geochem. 2003, 54, 1-29. [CrossRef]

42. Kawasaki, K.; Buchanan, A.V.; Weiss, K.M. Biomineralization in humans: Making the hard choices in life. Annu. Rev. Genet. 2009, 43, 119-142. [CrossRef] [PubMed]

43. Shearer, D.; Ens, W.; Standing, K.; Valdimarsson, G. Posttranslational modifications in lens fiber connexins identified by off-line-HPLC MALDI-quadrupole time-of-flight mass spectrometry. Investig. Ophthalmol. Vis. Sci. 2008, 49, 1553-1562. [CrossRef]

44. Yin, X.; Liu, J.; Jiang, J.X. Lens fiber connexin turnover and caspase-3-mediated cleavage are regulated alternately by phosphorylation. Cell Commun. Adhes. 2008, 15, 1-11. [CrossRef]

45. Wang, Z.; Schey, K.L. Phosphorylation and truncation sites of bovine lens connexin 46 and connexin 50. Exp. Eye Res. 2009, 89, 898-904. [CrossRef]

46. Wang, Z.; Han, J.; David, L.L.; Schey, K.L. Proteomics and phosphoproteomics analysis of human lens fiber cell membranes. Investig. Ophthalmol. Vis. Sci. 2013, 54, 1135-1143. [CrossRef] [PubMed]

47. Myers, J.B.; Haddad, B.G.; O’Neill, S.E.; Chorev, D.S.; Yoshioka, C.C.; Robinson, C.V.; Zuckerman, D.M.; Reichow, S.L. Structure of native lens connexin 46/50 intercellular channels by cryo-EM. Nature 2018, 564, 372-377. [CrossRef] [PubMed]

48. Retamal, M.A.; Orellana, V.P.; Arévalo, N.J.; Rojas, C.G.; Arjona, R.J.; Alcaíno, C.A.; González, W.; Canan, J.G.; Moraga-Amaro, R.; Stehberg, J.; et al. Cx46 hemichannel modulation by nitric oxide: Role of the fourth transmembrane helix cysteine and its possible involvement in cataract formation. Nitric Oxide 2019, 86, 54-62. [CrossRef] 
49. Retamal, M.A.; Fiori, M.C.; Fernandez-Olivares, A.; Linsambarth, S.; Peña, F.; Quintana, D.; Stehberg, J.; Altenberg, G.A. 4-Hydroxynonenal induces Cx46 hemichannel inhibition through its carbonylation. Biochim. Biophys. Acta Mol. Cell Biol. Lipids 2020, 1865, 158705. [CrossRef]

50. Berthoud, V.M.; Beyer, E.C.; Kurata, W.E.; Lau, A.F.; Lampe, P.D. The gap-junction protein connexin 56 is phosphorylated in the intracellular loop and the carboxy-terminal region. Eur. J. Biochem. 1997, 244, 89-97. [CrossRef]

51. Cheng, H.-L.; Louis, C.F. Endogenous casein kinase I catalyzes the phosphorylation of the lens fiber cell connexin49. Eur. J. Biochem. 1999, 263, 276-286. [CrossRef] [PubMed]

52. Berthoud, V.M.; Westphale, E.M.; Grigoryeva, A.; Beyer, E.C. PKC isoenzymes in the chicken lens and TPA-induced effects on intercellular communication. Investig. Ophthalmol. Vis. Sci. 2000, 41, 850-858.

53. Cheng, H.-L.; Louis, C.F. Functional effects of casein kinase I-catalyzed phosphorylation on lens cell-to-cell coupling. J. Membr. Biol. 2001, 181, 21-30. [CrossRef]

54. Liu, J.; Ek Vitorin, J.F.; Weintraub, S.T.; Gu, S.; Shi, Q.; Burt, J.M.; Jiang, J.X. Phosphorylation of connexin 50 by protein kinase A enhances gap junction and hemichannel function. J. Biol. Chem. 2011, 286, 16914-16928. [CrossRef]

55. Martinez, J.M.; Wang, H.Z.; Lin, R.Z.; Brink, P.R.; White, T.W. Differential regulation of Connexin50 and Connexin46 by PI3K signaling. FEBS Lett. 2015, 589, 1340-1345. [CrossRef]

56. Berthoud, V.M.; Bassnett, S.; Beyer, E.C. Cultured chicken embryo lens cells resemble differentiating fiber cells in vivo and contain two kinetic pools of connexin56. Exp. Eye Res. 1999, 68, 475-484. [CrossRef]

57. Yin, X.; Jedrzejewski, P.T.; Jiang, J.X. Casein kinase II phosphorylates lens connexin 45.6 and is involved in its degradation. J. Biol. Chem. 2000, 275, 6850-6856. [CrossRef]

58. Eckert, R. pH gating of lens fibre connexins. Pflüg. Arch. 2002, 443, 843-851. [CrossRef]

59. Lin, J.S.; Eckert, R.; Kistler, J.; Donaldson, P. Spatial differences in gap junction gating in the lens are a consequence of connexin cleavage. Eur. J. Cell Biol. 1998, 76, 246-250.

60. Stergiopoulos, K.; Alvarado, J.L.; Mastroianni, M.; Ek-Vitorin, J.F.; Taffet, S.M.; Delmar, M. Hetero-domain interactions as a mechanism for the regulation of connexin channels. Circ. Res. 1999, 84, 1144-1155. [CrossRef]

61. Xu, X.; Berthoud, V.M.; Beyer, E.C.; Ebihara, L. Functional role of the carboxyl terminal domain of human connexin 50 in gap junctional channels. J. Membr. Biol. 2002, 186, 101-112. [CrossRef] [PubMed]

62. DeRosa, A.M.; Mui, R.; Srinivas, M.; White, T.W. Functional characterization of a naturally occurring Cx50 truncation. Investig. Ophthalmol. Vis. Sci. 2006, 47, 4474-4481. [CrossRef] [PubMed]

63. Yin, X.; Gu, S.; Jiang, J.X. The development-associated cleavage of lens connexin 45.6 by caspase-3-like protease is regulated by casein kinase II-mediated phosphorylation. J. Biol. Chem. 2001, 276, 34567-34572. [CrossRef] [PubMed]

64. Gao, J.; Wang, H.; Sun, X.; Varadaraj, K.; Li, L.; White, T.W.; Mathias, R.T. The effects of age on lens transport. Investig. Ophthalmol. Vis. Sci. 2013, 54, 7174-7187. [CrossRef]

65. Evans, J.S. The biomineralization proteome: Protein complexity for a complex bioceramic assembly process. Proteomics 2019, 19, e1900036. [CrossRef]

(C) 2020 by the authors. Licensee MDPI, Basel, Switzerland. This article is an open access article distributed under the terms and conditions of the Creative Commons Attribution (CC BY) license (http://creativecommons.org/licenses/by/4.0/). 